Jurnal Riset Manajemen Sains Indonesia (JRMSI) | Vol 7, No. 1, 2016

\title{
EFFECT OF EXTERNAL ENVIRONMENT ORGANIZATION AND APPLICATION OF TOTAL QUALITY MANAGEMENT (TQM) AND PERFORMANCE OF THE COMPANY AND ITS EFFECT ON COMPETITIVE ADVANTAGE IN PT ISM BOGASARI FLOURMILLS, JAKARTA
}

\author{
Ana Retno Mawarti \\ PT ISM Bogasari Flourmills \\ Email: amawarti@gmail.com
}

\begin{abstract}
This research aimed to discover the impact of external environment and Total Quality Management implementation on company performance in order to create competitive advantage in PT. ISM Bogasari Flourmills. This research is an associative explanatory research with quantitative method. The data sources used are primary data and secondary data. The primary data collected by spreading 122 questionnaires to employees of PT. ISM Bogasari on chief officers level, assistant manager level, and manager level. Sampling method used is Proportionable Stratified Random Sampling.

The result showed that external environment with indicator of complexity, dynamics and environment carrying capacity, has positive and significant impact on company's performance. Total Quality Management implementation with indicators of costumer focus, continuous refinement and staff training program, brings positive and significant impact on company's performance. The company's performance with its indicators of efficiency, effectiveness, and adaptability, has positive and significant impact on the creation of competitive advantage. The Research also proved that external environment and Total Quality Management Implementation directly affect the creation of competitive advantage.
\end{abstract}

Keywords: External environment, Total Quality Management implementation, company's performance, and competitive advantage 
Jurnal Riset Manajemen Sains Indonesia (JRMSI) | Vol 7, No. 1, 2016

\section{PENDAHULUAN}

\section{Latar Belakang}

Industri tepung terigu adalah salah satu industri yang mengalami perubahan bisnis yang cepat sejak pertama kali diregulasi sektor pangan dilakukan pada tahun 1997. Diregulasi sektor pangan dimulai dengan diputuskannya Keppres RI No. 45 Tahun 1997 menyangkut penciutan tugas pokok Bulog yang hanya mengelola komoditi beras dan gula pasir. Selanjutnya turun Keppres RI No. 19 Tahun 1998 tentang perubahan tugas pokok Bulog yang hanya mengatur pengadaan beras saja. Kedua deregulasi tersebut secara langsung membawa konsekuensi ekonomi dan politik dalam industri tepung terigu di Indonesia, dari sebuah industri tertutup yang hanya menerima jasa penggilingan dari pemerintah menjadi industri yang bersaing secara terbuka . Adanya Deregulasi ini membuat PT. ISM Bogasari yang semula memonopoli pasar tepung terigu kini harus bersaing sesuai permintaan pasar. Dengan semakin banyaknya industri tepung terigu yang berdiri menyebabkan kondisi persaingan semakin ketat.

Pertumbuhan industri tepung terigu dalam negeri juga dipicu oleh beberapa faktor seperti peningkatan kesadaran bahwa tepung terigu adalah merupakan bahan dasar yang akan menghasilkan makanan yang sehat dan bergizi, peningkatan konsumsi makanan berbasis tepung terigu sebagai alternatif diversifikasi pangan serta adanya kesadaran lebih baik untuk memproduksi di negeri sendiri tepung terigu untuk menjaga kualitas dan kandungan gizi tepung terigu seperti yang tertuis dalam buku Prospek dan Perkembagan Tepung Terigu diindonesia, Pertumbuhan kapasitas produksi tepung terigu dari tahun 2005 sd 2012 rata rata berkisar 5.8\%, dengan jumlah industry tepung terigu yang hingga tahun 2012 saat ini ada di Indonesia berjumlah 21 produsen tepung terigu.

Dalam menghadapi persaingan, PT. ISM Bogasari memerlukan upaya perbaikan berkesinambungan terhadap kemampuan sumber daya manusia, proses dan lingkungan untuk menghasilkan kualitas produk yang terbaik. Cara terbaik untuk memperbaiki komponen - komponen sumber daya manusia, proses dan lingkungan tersebut secara berkesinambungan adalah dengan menerapkan Total Quality Management. Dalam 
meningkatkan kualitas produk dan jasa, perusahaan harus melakukan peningkatan dari segi kualitas, inovasi, kreatifitas, dan produktifitas secara konsisten agar dapat menghasilkan produk akhir yang bernilai positif lebih tinggi serta jasa yang pelayanannya lebih baik sehingga dapat memenuhi kepuasan para pelanggan. Waldman menyatakan bahwa TQM merupakan suatu sistem yang dirancang sebagai kesatuan yang memfokuskan pendekatan pelanggan dengan meningkatkan kualitas produk dan layanan untuk konsumen

Dengan mengoptimalkan kinerja yang dimiliki oleh PT. ISM Bogasari FM, maka diharapkan akan diperoleh keunggulan bersaing yang berkelanjutan (sustained competitive advantage). Menurut Barney dalam Firm Resources and Sustained Competitive Advantage, Kompetensi yang dimilki akan menjadi sumber keunggulan bersaing ketika kompetensi yang dimiliki adalah kompetensi yang bernilai, langka, sulit ditiru dan sulit digantikan.

\section{Identifikasi Masalah}

Adanya peningkatan konsumsi tepung terigu memicu investor untuk melakukan investasi pada industri tepung terigu, Seiiring dengan pertumbuhan investasi pada industri tepung terigu, akan sangat mempengaruhi posisi PT. ISM Bogasari selaku market leader untuk industri tepung terigu, Untuk dapat mempertahankan posisi sebagai market leader PT.ISM Bogasari FM harus mampu beradapatasi dengan lingkungan eksternal serta mengoptimalkan penerapan TQM untuk dapat meningkatkan kinerja yang dapat menciptaka keunggulan bersaing, sehingga dapat memenangkan persaingan dengan pesaingnya.

\section{KAJIAN TEORITIK}

\section{Keunggulan Bersaing}

Menurut Porter dalam competitive advantage menjelaskan bahwa keunggulan bersaing (competitive advantage) adalah jantung kinerja dalam melakukan kerjasama untuk menciptakan keunggulan bersaing yang lebih efektif dalam pasarnya. Strategi ini harus didesain untuk mewujudkan keunggulan bersaing yang terus menerus sehingga perusahaan dapat mendominasi baik di pasar lama maupun pasar baru. Keunggulan 
daya saing dapat juga diartikan keuntungan perusahaan yang lebih tinggi dibandingkan perusahaan pesaing dalam sektor industri yang sama. Secara konseptual, keunggulan daya saing adalah merupakan kemampuan suatu bisnis dalam memperoleh keuntungan abnormal dalam industri kompetitif berdasarkan strategi penciptaan nilai. Dengan kata lain keunggulan daya saing merupakan pelaksanaan yang lebih unggul dari strategi yang dipakai oleh pesaing. Keunggulan daya saing akan sustainable jika keunggulannya dapat dipertahankan dari peniruan atau duplikasi tindakan pesaing. Terdapat 4 (empat) esensi persyaratan dari sumberdaya dan keterampilan agar dapat dikatakan sebagai sumberdaya dari keunggulan bersaing adalah : haruslah bernilai, jarang atau unik dari perusahaan lainnya, bentuknya untuk dapat dilakukan peniruan sangatlah sulit karena produk/jasa tersebut sempurna serta tidak mudah untuk dapat digantikan dengan sumberdaya yang lainnya .

\section{Kinerja Perusahaan}

Menurut Hansen dan Mowen dalam management accounting menjelaskan bahwa Penilaian kinerja aktivitas pusat dibagi kedalam tiga dimensi utama, yaitu: (1) effisiensi, (2) kualitas, (3) waktu. Untuk mengantisipasi tidak tersedianya data -data kinerja dalam sebuah penelitian, maka dimungkinkan untuk mengunakan ukuran subyektif yang mendasar pada persepsi staff dan manager perusahaan atas berbagai dimensi pengukuraan kinerja perusahaan seperti yang dikemukakan oleh Beal dalam Journal Competing Effectively : Environment Scanning, Competitive Strategy \& Organization Performance in Small Manufacturing Firms". Journal of Small Business Managemen.

Ukuran kinerja juga dibuktikan oleh Zahra dan Das bahwa ukuran kinerja subyektif memiliki tingkat reliabilitas dan validitas yang tinggi. Disamping itu berdasarkan penelitian Voss menunjukkan adanya korelasi yang erat antara ukuran kinerja subyektif dan obyektif. Tiga kriteria yang disarankan Dinda Estika Asmarani dalam pengukuran kinerja yaitu Efektifitas, Efisiensi dan adaptabilitas. Efektifitas didefinisikan sebagai keberhasilan produk dan program - program yang dijalankan perusahaan dibandingkan dengan pesaingnya . Efisiensi diterjemahkan sebagai hasil dari program - program 
bisnis yang dijalankan perusahaan dalam kaitannya dengan jumlah sumber daya yang digunakan untuk program - program usaha dalam organisasi tersebut. Adaptabilitas menunjukan kemampuan perusahaan untuk dapat merespon perubahan - perubahan yang terjadi dipasar dan hal ini dicerminkan dalam keberhasilan produk ataupun pelayanan oleh perusahaan

\section{Lingkungan Eksternal}

Para pembuat keputusan dalam suatu organisasi seharusnya tidak hanya memusatkan perhatiannya pada lingkungan internal organisasi, tetapi juga menyadari pentingnya pengaruh lingkungan eksternal terhadap organisasi yang dikelolanya. Manajemen dituntut untuk selalu bersikap tanggap dan adaptif, selalu mengikuti dan menyesuaikan diri dengan keadaan lingkungan. Dengan memperhatikan hal - hal tersebut akan memungkinkannya menjaga dan mengembangkan organisasi dalam lingkungan yang selalu berubah.seperti dikutip dari David Hunger and Thomas Wheelen dalam Strategic management and business policy . Pengamatan terhadap lingkungan adalah merupakan proses penting dalam management strategik, sebab merupakan mata rantai yang pertama dalam tindakan dan persepsi yang memungkinkan suatu organisasi untuk menyesuaikan diri dengan lingkungan. Dimensionalisasi lingkungan eksternal dari Des dan beard, yang paling banyak diadopsi dalam penelitian terdiri dari tiga konseptualisasi lingkungan eksternal, yaitu kompleksitas lingkungan, Dinamika Lingkungan dan daya dukung lingkungan. Kompleksitas lingkungan mengacu pada banyaknya (jumlah) dan heterogenitas sektor - sektor lingkungan eksternal yang harus dihadapi . Dinamikan lingkungan eksternal mengacu pada instabilitas dan volatilitas lingkungan eksternal. Sedangkan komplesksitas menunjukan pada jumlah sektor

lingkungan eksternal sedangkan dinamika mengacu pada perubahan lingkungan eksternal. Daya dukung lingkungan eksternal mengacu pada jumlah sumber daya yang disediakan oleh lingkungan eksternal dalam mendukung pertumbuhan organisasi

\section{TOTAL Quality Management (TQM)}

Hansen dan Mowen dalam management accounting mengemukakan bahwa Total Quality Management adalah suatu perbaikan berkelanjutan yang mana hal ini adalah 
sesuatu yang mendasar sifatnya bagi pengembangan proses manufakturing yang sempurna. Total Quaity Management juga diterjemahkan sebagai pendekatan berorientasi pelanggan yang memperkenalkan perubahan manajemen yang sistematik dan perbaikan terus menerus terhadap proses, produk, dan pelayanan suatu organisasi. Total Quality Management merupakan paradigma baru dalam menjalankan bisnis yang berupaya memaksimumkan daya saing organisasi melalui : fokus pada kepuasan konsumen, keterlibatan seluruh karyawan, dan perbaikan secara berkesinambungan atas kualitas produk, jasa, manusia, proses dan lingkungan organisasi , hal ini disampaikan oleh Krajewski, J. Lee and P. R. Larry. Operations Management Strategy and Analysis, Total Quality Management memainkan peranan yang sangat penting dalam meningkatkan kekuatan daya saing perusahaan. Di dalam pasar global yang berubah secara terus menerus, disamping pengiriman yang cepat (speed of delivery), kualitas produk juga menjadi salah satu elemen yang penting bagi perusahaan untuk dapat bersaing (competition). Total Quality Management (TQM) merupakan pendekatan yang seharusnya dilakukan organisasi masa kini untuk memperbaiki kualitas produknya, menekan biaya produksi dan meningkatkan produktivitasnya.

\section{KERANGKA TEORITIK}

Penelitian yang dilakukan pada saat ini juga memfokuskan pada variabel lingkungan eksternal dan penerapa total quality management dalam meningkatkan kinerja yang akan berdampak pada terciptanyta keunggulan bersaing.

Dan berdasrkan telaah pustaka dan hasil penelitian terdahulu, peneliti menyusun kerangka pemikiran untuk mengetahui faktor lingkungan eksternal dan penerapan Total quality Management bagi terciptanya keunggulan bersaing dengan model kerangka pemikiran sebagai berikut : 


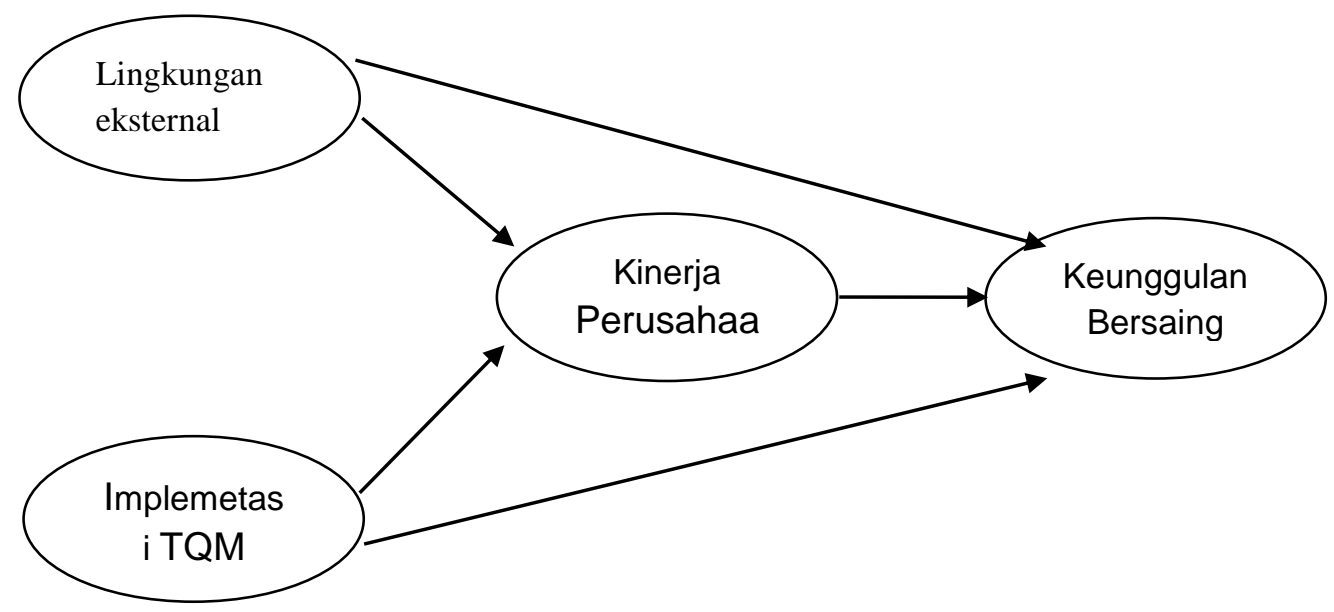

\section{HIPOTESA PENELITIAN}

\section{PERUMUSAN HIPOTESIS}

- H1 : Lingkungan eksternal berpengaruh positif terhadap kinerja perusahaan

- H2 : Penerapan Total Quality Management berpengaruh positif terhadap kinerja perusahaan

- H3 : Kinerja Perusahaan berpengaruh positif dalam terciptanya keunggulan bersaing.

- H4 : Lingkungan Eksternal berpengaruh positif dalam terciptanya keunggulan bersaing

- H5: Penerapan Total Quality Management berpengaruh positif dalam terciptanya keunggulan bersaing.

\section{METODE PENELITIAN}

Metode penelitian yang akan digunakan oleh peneliti terdiri dari jenis dan sumber data, populasi dan sampel, metode pengumpulan data serta teknik analisa data Metode penelitian yang digunakan adalah kuantitatif. Gambaran populasi yang dijadikan responden pada PT Indofood CBP Sukses Makmur Divisi Bogasari Flour Mills terdiri dari Manajer, Asisten Manager dan kepala bagian dengan jumlah populasi yang terdiri dari 180 orang terdiri dari 15 orang Manager, 35 orang asst maager serta 130 orang kepala bagian Teknik pengambilan sampel yang akan digunakan dalam 
penelitian ini menggunakan Proportionate Stratified Random Sampling. Jumlah sampel dalam penelitian ini dengan proporsi level sebagai koresponden sebagai berikut 10 orang sebagia manager, 23 orang Asst Manager serta 87 kepala bagian.

\section{Uji Validitas dan reliabilitas}

Sebelum dilakukan uji statistik dilakukan terlebih dahulu dilakukan Uji Validitas dan realibilitas . Uji validitas digunakan untuk mengukur sah atau valid tidaknya suatu kuesioner. Uji validitas dilakukan dengan korelasi Pearson. Sedangkan uji reliabilitasa adalah reliabilitas adalah derajat ketepatan, ketelitian, atau keakuratan yang ditunjukkan oleh instrument pengukuran dimana pengujian dengan menghasilkan konsisten butirbutir yang ada. Pengujian statistik crobach'alpha, instrumen dikatakan reliabel untuk mengukur variabel bila memiliki nilai alpha lebih besar dari 0,60.

\section{HASIL PENELITIAN DAN PEMBAHASAN}

\section{Deskripsi Responden}

Peneliti memperoleh data primer dari penyebaran questioner yang dilakukan dari tanggal 01 Juni sampai dengan tanggal 15 Agustus 2014. Peneliti memberikan questioner pada responden melalui kunjungan langsung serta melakukan wawancara langsung. Jumlah questioner yang disebar adalah sebanyak 122 dengan rician deskripsi responden sebagai berikut :

Tabel 1. Deskripsi Responde

\begin{tabular}{cccc}
\hline No & Uraian & $\begin{array}{c}\text { Jumlah } \\
\text { Orang }\end{array}$ & Persentase \\
1 & Jabatan & & \\
& a. Manager & 10 & $10.80 \%$ \\
& b. Asst Manager & 23 & $23,19 \%$ \\
& c. Kepala bagian & 87 & $87.73 \%$ \\
Lama bekerja & & \\
a.3-5 th & 13 & $10.83 \%$ \\
b. 5-10 th & 22 & $18.33 \%$ \\
& c. lebih dar 10 & 85 & $70.83 \%$ \\
\hline
\end{tabular}




\section{PENGUJIAN HIPOTESIS}

\section{Uji Asumsi Klasik}

\section{Uji Normalitas}

Uji normalitas bertujuan untuk menguji apakah dalam model regresi, variabel pengganggu atau residual memiliki distribusi normal.

\section{Berikut Hasil uji normalitas dengan kinerja sebagai variabel dependent}

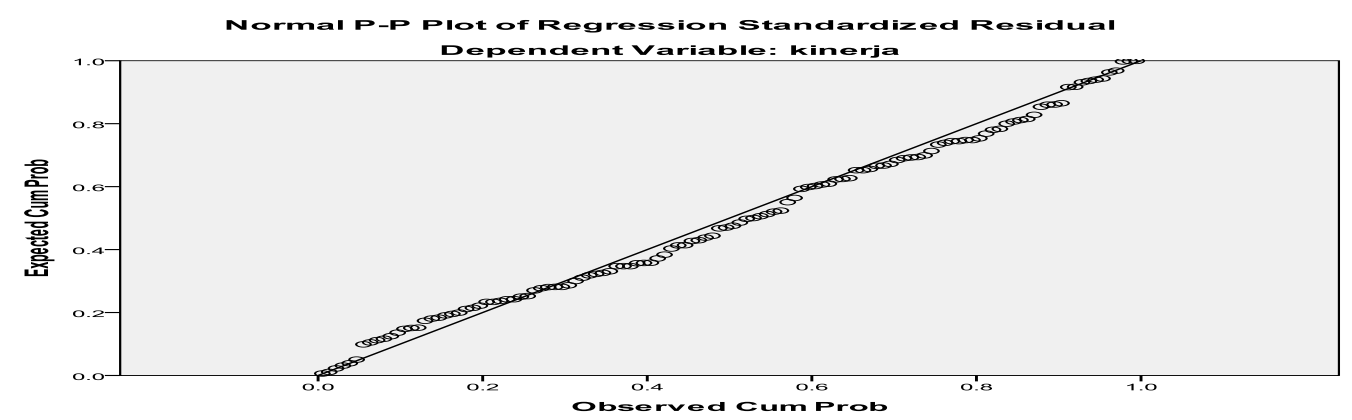

Dengan melihat tampilan grafik normal plot dapat disimpulkan bahwa grafik histogram dengan kinerja sebagai variable dependent memberikan pola distribusi normal,

\section{Berikut Hasil uji normalitas dengan daya saing sebagai variabel dependent}

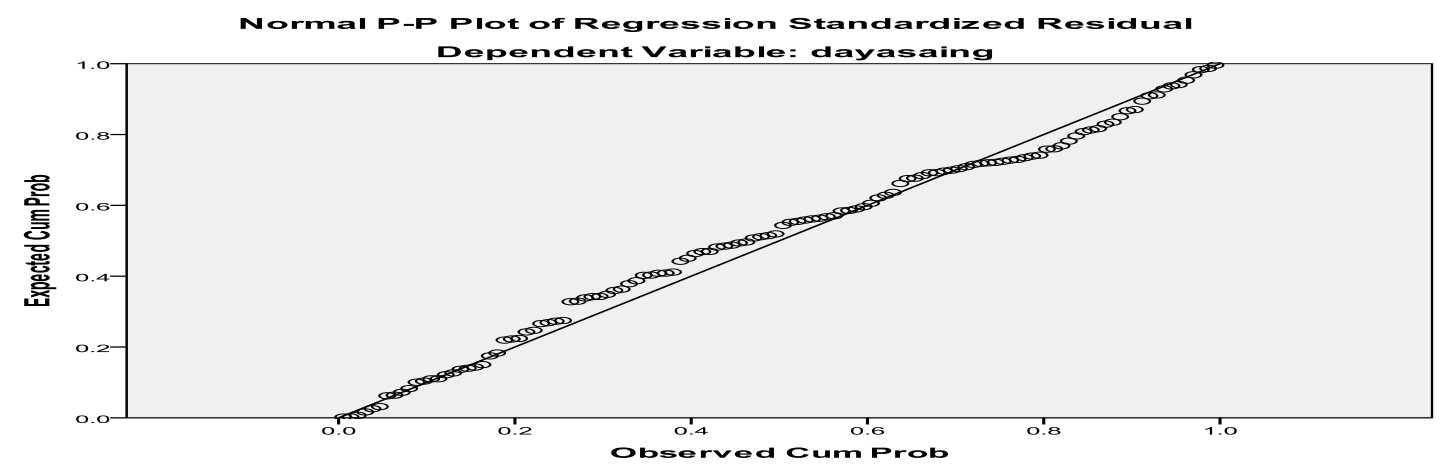

Dengan melihat tampilan grafik normal plot dapat disimpulkan bahwa grafik histogram dengan daya saing sebagai variabel dependent memberikan pola distribusi normal. 


\section{Uji Multikolonieritas}

Nilai VIF (Variance Inflation Factor) yang dihasilkan dengan pengolahan SPSS dengan kinerja sebagai variabel dependent memiliki hasil lebih dari 10. Jadi dapat disimpulkan bahwa tidak ada multikolonieritas antar variabel independent ( Lingk Eksternal dan Penerapan TQM) yang menyusun variabel dependent Kinerja . Berdasarkan pengolahan data denga variabel dependent Daya saing, didapatkan hasil Tolerance dan Variance Inflation Factor (VIF) juga dihasilkan nilai lebih besar dari 10, dan dapat disimpulkan bahwa tidak ada multikolonieritas antar variabel independent ( Lingk Eksternal, Penerapan TQM serta kinerja) dalam model regresi.

\section{Uji Autokorelasi}

Pengujian autokorelasi menggunakan uji Durbin- Watson (DW).untuk variabel dependent kinerja. Dihasilkan Nilai DW sebesar 2.132 nilai ini akan dibandingkan dengan nilai tabel dengan menggunakan nilai signifikansi 5\%, maka di tabel DW akan didapatkan nilai $\mathrm{dL}=1.6684$ dan $\mathrm{dU}=1.7361$. Oleh karena nilai DW 2.132 lebih besar dari batas atas (du) 1.7361 dan kurang dari 4- 1.7361= 2.2639 (4- du), maka dapat disimpulkan bahwa tidak terdapat autokorelasi

pengujian autokorelasi menggunakan uji Durbin- Watson (DW).untuk variabel dependent Daya saing didapatkan nilai DW sebesar 1.851 sedangkan di tabel DW akan didapatkan nilai $\mathrm{dL}=1.6513$ dan $\mathrm{dU}=1.7536$ Oleh karena nilai DW 1.851 lebih besar dari batas atas (du) 1.7536 dan kurang dari 4- 1.7536= 2.2464 (4- du), maka dapat disimpulkan bahwa tidak terdapat Autokorelasi.

\section{Uji Heteroskedastisitas}

Dengan melalui uji white yaitu (White's General Heterokedasticity Test), Untuk variabel dependent kinerja , dari hasil olahan data didapatkan nilai chi square $(\mathrm{sig})>$ o.05. Oleh karena itu dapat dikatakan model persamaan yang digunakan tidak mengalami masalah heterokedastisitas, Sedangkan untuk variabel dependent daya 
saing, didapatkan hasil uji nilai chi square $(\operatorname{sig})>0.05$. Oleh karena itu dapat dikatakan model persamaan yang digunakan tidak mengalami masalah heterokedastisitas

\section{UJI HIPOTESA}

Pengaruh lingkungan eksternal dan penerapan total quality management terhadap kinerja

Untuk mengetahui besarnya pengaruh lingkungan eksternal dan penerapan Total Quality Management secara parsial dapat dilihat

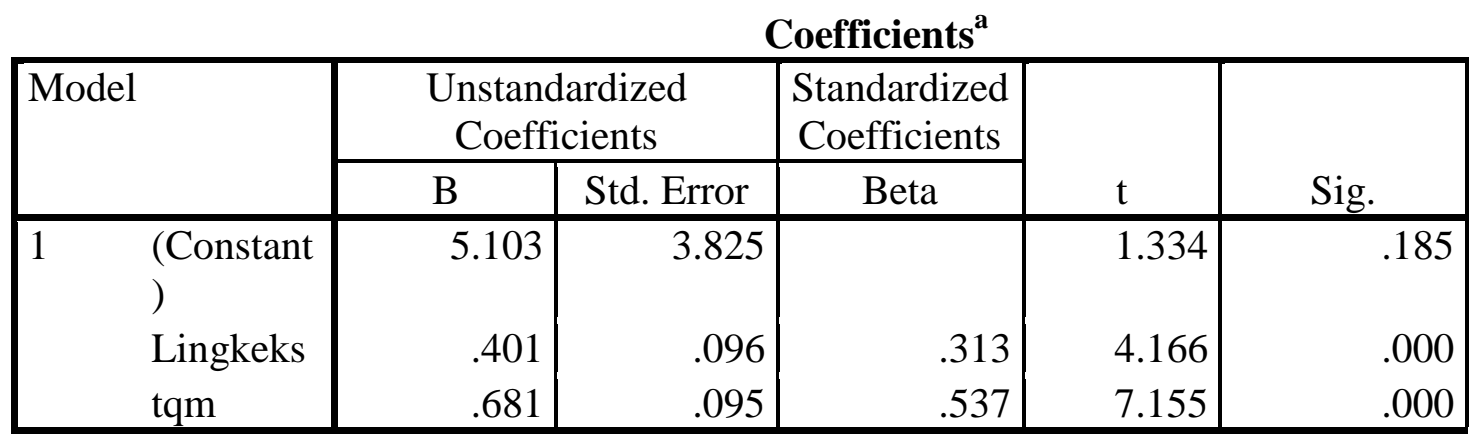

a. Dependent Variable: kinerja

Dengan kriteria pengujian kita bisa bandingkan thitung dengan $\mathrm{t}$ tabel yaitu :

Jika t hitung $>\mathrm{t}$ tabel maka Ho ditolak

Jika thitung $<\mathrm{t}$ tabel maka Ho diterima.

Untuk menunjukan pengaruh yang signifikan atau tidak kriterianya sebagai berikut :

Jika sig $<0.05$ maka terdapat pengaruh yang signifikan

Jika sig .0.05 maka pengaruh tidak signifikan

\section{Hipotesa 1 yang akan diuji adalah}

HO : Tidak ada hubungan linear antara variabel independen exogenous lingkungan eksternal dengan variabel dependen kinerja

H1 : Ada hubungan linear antara variabel independen exogenous lingkungan eksternal dengan variabel dependen kinerja

Dari tabel diatas didapatkan nilai t hitung adalah 4.166. t tabel 1.9804 , artinya $\mathrm{t}$ hitung $>\mathrm{t}$ tabel, sehingga H0 ditolak dan H1 diterima. Dengan demikkian dapat dikatakan bahwa terdapat hubungan linear lingkungan eksternal dengan kinerja perusahaan. Besarnya pengaruh lingkungan eksternal terhadap kinerja dapat diketahui 
dari nilai koefisien beta ( dalam kolom standardized coefisient beta ) sebesar 0.313 atau $31.3 \%$. Dari tabel diatas didapatkan nilai sig sebesar $0.000<\alpha=0,05$.

\section{Hipotesa 2 yang akan diuji adalah :}

H0 : Tidak ada hubungan linear antara variabel independen exogenous Total Quality Management dengan variabel dependen kinerja

H1 : Ada hubungan linear antara variabel independen exogenous Total Quality Management dengan variabel dependen kinerja

Dari tabel diatas didapatkan nilai t hitung adalah 7.155. $\mathrm{t}$ tabel 1.9804 , artinya $\mathrm{t}$ hitung $>\mathrm{t}$ tabel, sehingga $\mathrm{H} 0$ ditolak dan H1 diterima. Dengan demikkian dapat dikatakan bahwa terdapat hubungan linear Total Quality management dengan kinerja perusahaan. Besarnya pengaruh Total Quality management terhadap kinerja dapat diketahui dari nilai koefisien beta ( dalam kolom standardized coefisient beta ) sebesar 0.537 atau 53.7\%. Persamaan yang dihasilkan adalah $: Y=0.313 X 1+0.537 \mathrm{X} 2+\varepsilon 1$

\section{Uji F}

\begin{tabular}{|c|c|c|c|c|c|c|}
\hline \multicolumn{7}{|c|}{ ANOVA $^{b}$} \\
\hline & & $\begin{array}{l}\text { Sum of } \\
\text { Squares }\end{array}$ & $\mathrm{df}$ & $\begin{array}{l}\text { Mean } \\
\text { Square }\end{array}$ & $\mathrm{F}$ & Sig. \\
\hline 1 & $\begin{array}{l}\text { Regression } \\
\text { Residual } \\
\text { Total }\end{array}$ & $\begin{array}{l}1553.053 \\
1063.538 \\
2616.592\end{array}$ & $\begin{array}{r}2 \\
117 \\
119\end{array}$ & $\begin{array}{r}776.527 \\
9.090\end{array}$ & 85.426 & $.000^{\mathrm{a}}$ \\
\hline
\end{tabular}

a. Predictors: (Constant), tqm, lingeks

b. Dependent Variable: kinerja

Kriteria pengambilan keputusan dari uji hipotesa adalah :

JIka F hitung > F tabel, maka H0 ditolak dan H1 diterima

Jika F hitung < F tabel, maka $\mathrm{H} 0$ diterima dan $\mathrm{H} 1$ ditolak.

H0 : Tidak ada hubungan linear antara variabel independent exogenous lingkungan eksternal dan penerapa total quality management terhadap kinerja

H1 : Ada hubungan linear antara variabel independent exogenous lingkungan eksternal dan penerapa total quality management terhadap kinerja

Dari hasil pengujian didapatkan bahwa nilai $\mathrm{F}$ hitung $>\mathrm{F}$ tabel, dengan demikian H0 ditolak dan H1 diterima, selain itu pada kolom sig, hasil yang didapatkan $<0.05$, 
dengan demikian dapat dikatakan terdapat pengaruh secara signifikan. Sehingga dapat dikatakan bahwa variabel lingkungan eksternal dan penerapan total quality management secara bersama - sama mempengaruhi secara signifikan terhadap kinerja.

Pengaruh variabel lingkungan eksternal,penerapan total quality management serta kinerja terhadap keunggulan bersaing sebagai variabel dependent.

Sedangkan untuk melihat pengaruh variabel independent lingkungan eksternal , penerapan total quality management serta kinerja terhadap keunggulan bersaing secara sendiri - sendiri dilakukan dengan uji t

Uji $\mathbf{t}$

Dari pengolahan Spss didapatkan hasil t hitung :

Tabel 4.5. Hasil Uji t ( $\mathbf{Z}=\boldsymbol{\rho} \mathbf{y} \mathbf{X} \mathbf{1}+\boldsymbol{\rho} \mathbf{y} \mathbf{X} \mathbf{2}+\boldsymbol{\rho z} \mathbf{y}+\mathbf{\varepsilon} 2)$

\begin{tabular}{|c|c|c|c|c|c|c|}
\hline \multirow{2}{*}{\multicolumn{2}{|c|}{ Model }} & \multicolumn{2}{|c|}{$\begin{array}{l}\text { Unstandardized } \\
\text { Coefficients }\end{array}$} & \multirow{2}{*}{$\begin{array}{c}\begin{array}{c}\text { Standardized } \\
\text { Coefficients }\end{array} \\
\text { Beta }\end{array}$} & \multirow[b]{2}{*}{$\mathrm{t}$} & \multirow[b]{2}{*}{ Sig. } \\
\hline & & B & Std. Error & & & \\
\hline \multirow[t]{4}{*}{1} & (Constant) & 4.267 & 5.245 & & .813 & .418 \\
\hline & lingkeks & .381 & .141 & .227 & 2.709 & .008 \\
\hline & tqm & .336 & .155 & .203 & 2.163 & .033 \\
\hline & kinerja & .537 & .126 & .411 & 4.265 & .000 \\
\hline
\end{tabular}

a. Dependent Variable: dayasaing

nilai $\mathrm{t}$ tabel $=1.98063$,

\section{Hipotesa 3 yang akan diuji adalah ::}

H0 : Tidak ada hubungan linear antara variabel independen exogenous lingkungan eksternal dengan variabel dependen Keunggula bersaing

H1 : Ada hubungan linear antara variabel independen exogenous lingkungan eksternal dengan variabel dependen Keunggulan bersaing

Dari tabel diatas didapatkan nilai t hitung adalah 2.709. $\mathrm{t}$ tabel -1.98063 , artinya $\mathrm{t}$ hitung > t tabel, sehingga H0 ditolak dan H1 diterima. Denga nilai koefisen beta sebesar 0.227 atau 22.7\%. Dari tabel diatas didapatkan nilai sig sebesar $0.008<\alpha=0,05$. 


\section{Hipotesa 4 yang akan diuji adalah :}

H0 : Tidak ada hubungan linear antara variabel independen exogenous Total Quality Management dengan variabel dependen Keunggulan bersaing

H1 : Ada hubungan linear antara variabel independen exogenous Total Quality Management dengan variabel dependen keunggula bersaing

Dari tabel diatas didapatkan nilai t hitung adalah 2.165. $t$ tabel 1.98063 , artinya $t$ hitung > t tabel, sehingga $\mathrm{H} 0$ ditolak dan $\mathrm{H} 1$ diterima . dengan nilai koefisien beta ( dalam kolom standardized coefisient beta ) sebesar 0.203 atau 20.3\%. Dari tabel diatas didapatkan nilai sig sebesar $0.033<\alpha=0,05$. Dengan demikan dapat disimpulkan bahwa

Pengaruh yang signifikan antara penerapan Total Quality Management dengan terciptanya keunggulan bersaing.

\section{Hipotesa 5 yang akan diuji}

H0 : Tidak ada hubungan linear antara variabel independen exogenous kinerja dengan variabel dependen Keunggulan bersaing

H1 : Ada hubungan linear antara variabel independen exogenous kinerja dengan variabel dependen keunggula bersaing.

Dari tabel diatas didapatkan nilai t hitung adalah 4.265. $\mathrm{t}$ tabel -1.98063 , artinya $\mathrm{t}$ hitung > t tabel, sehingga H0 ditolak dan H1 diterima . dengan nilai koefisien beta ( dalam kolom standardized coefisient beta ) sebesar 0.411 atau 20.3\%. Dari tabel diatas didapatkan nilai sig sebesar $0.000<\alpha=0,05$. Dengan demikan dapat disimpulkan bahwa Pengaruh yang signifikan antara kinerja dengan terciptanya keunggulan bersaing. Uji F

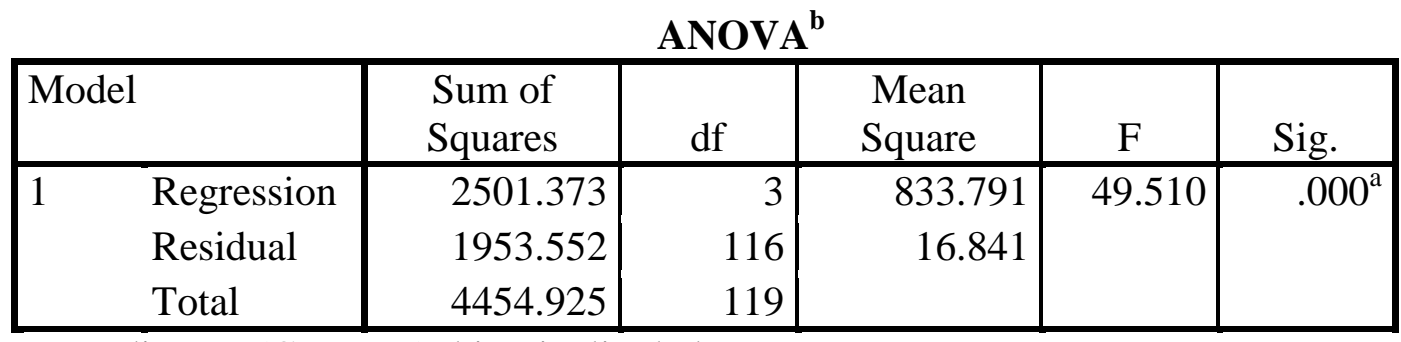

a. Predictors: (Constant), kinerja, lingkeks, tqm

b. Dependent Variable: dayasaing 
H0 : Tidak ada hubungan linear antara variabel independent exogenous lingkungan eksternal, penerapan total quality management, kinerja terhadap keunggulan bersaing

H1 : Ada hubungan linear antara variabel independent exogenous lingkungan eksternal, penerapan total quality management, kinerja terhadap keunggulan bersaing.

Nilai F hitung > F tabel, dengan demikian H0 ditolak dan H1 diterima, selain itu pada kolom sig, hasil yang didapatkan $<0.05$, dengan demikian dapat dikatakan terdapat pengaruh secara signifikan. Sehingga dapat dikatakan bahwa variabel lingkungan eksternal, penerapan total quality management, kinerja secara bersama sama mempengaruhi secara signifikan terhadap keunggulan bersaing.

Berdasarkan tabel diatas, didapatkan persamaan $Z=0.227 \times 1+0.203 X 2+0.411 y+\varepsilon$

\section{PEMBAHASAN HASIL PENELITIAN}

\section{Pengaruh Lingkungan Eksternal Terhadap Kinerja Perusahaan}

Lingkungan eksternal berpengaruh positif dan signifikan terhadap kinerja perusahaan Artinya indikator-indikator pada lingkungan eksternal yang meliputi daya dukung lingkungan, dinamika lingkungan, serta kompleksitas lingkungan, penting untuk dipantau dan dianalisa secara cermat. Dalam kajian management strategik, dikenal adanya proporsi yang menyebutkan bahwa kinerja perusahaan akan meningkat seiring dengan kemampuannya untuk beradapatasi dengan lingkungan eksternal. Lingkungan eksternal mempunyai peranan yang besar dalam mempengaruhi pengambilan keputusan managerial, proses dan struktur organisasi yang dapat meningkatkan kinerja perusahaan. Seperti yang dijelaskan oleh Keats BW and Hitt AK dalam causal model of linkages among environment al dimensions' Dengan kemampuan beradaptasi dengan lingkungan eksternal akan mendukung terjadinya peningkatan kinerja perusahaan yang lebih efektif dan efisien. Hasil penelitian ini sesuai dengan penelitian yang dilakukan oleh Aris Mardiyanto yang mendapatkan hasil bahwa lingkungan eksternal berpengaruh secara signifikan terhadap kinerja. 
Jurnal Riset Manajemen Sains Indonesia (JRMSI) | Vol 7, No. 1, 2016

\section{Pengaruh PenerapanTotal Quality Management Terhadap Kinerja Perusahaan}

Hasil pengujian hipotesis kedua yang diterima membuktikan adanya hubungan positif penerapan Total Quality Management dan kinerja perusahaan. Semakin baik penerapan Total Qulity Management maka akan meningkatkan kinerja perusahaan. Adanya penerapan Total Quality Management yang baik perusahaan akan dengan mudah mencapai tujuan organisasi yang telah ditetapkan. Artinya indikator-indikator yang berupa fokus pada pelanggan, perbaikan secara terus menrus serta adanya program pelatihan dan pendiidkan pada karyawan sangat berpengaruh pada peningkatan kinerja perusahaan.

\section{Pengaruh Kinerja Perusahaan terhadap terciptanya keunggulan bersaing}

Hasil pengujian hipotesa ketiga membuktikan bahwa ada hubungan yang yang posistif antara kinerja perusahaan dengan terciptanya keunggulan bersaing.Semakin tinggi kinerja perusahaan akan meningkatkan keunggulan bersaing. Berkaitan antara pengaruh kinerja perusahaan terhadap keunggulan bersainng dapat tercapai ketika kemampaun perusahaan untuk dapat beradaptasi dengan lingkungan luar perusahaan serta komitment perusahaan dalam rangka melakukan perbaikan secara terus menerus yang bertujuan untuk memberikan kepuasan pada pelanggan agar tahan terhadap keunggulan yang banyak terjadi peniruan, serta mampu menciptakan hambatan dalam jangka waktu yang lama. Dan diharapkan peningkatan kinerja tersebut akan mengahsilkan keuntungan yang lebih tinggi dibandingkan perusahaan pesaing dalam sektor industry yang sama. Kondisi ini yang akan menciptakan terwujudnya keunggulan bersaing.

\section{Pengaruh Lingkungan eksternal terhadap terciptanya keunggulan bersaing}

Hasil pengujian hipotesa keempat membuktikan bahwa ada hubungan yang positif antara lingkungan eksternal dengan terciptanya keunggulan bersaing. Kemampuan perusahaan dalam beradaptasi dengan kompleksitas serta dinamika lingkungan luar akan

mampu menciptakan keunggulan bersaing. Pengamatan lingkungan eksternal 
merupakan proses penting. Indikator-indikator yang berupa kompleksitas serta dinamika lingkungan eksternal apabila dapat diadaptasi oleh perusahaan, maka akan semakin meningkatkan terciptanya keunggulan bersaing.Hasil pengujian hipotesa keempat membuktikan bahwa ada hubungan yang positif antara lingkungan eksternal dengan terciptanya keunggulan bersaing. Kemampuan perusahaan dalam beradaptasi dengan kompleksitas serta dinamika lingkungan luar akan mampu menciptakan keunggulan bersaing. Pengamatan lingkungan eksternal merupakan proses penting . Lingkungan eksternal mempunyai peranan besar dalam mempengaruhi keputusan managerial, proses serta struktur organisasi dan penting untuk dipantau. Pengamatan terhadap lingkungan eksternal merupakan proses penting dalam management stategik, karena merupakan mata rantai yang pertama dalam tindakan yang memungkinkan suatu organisasi menyesuaikan diri dengan lingkungan. Perkembangan lingkungan eksternal yang penuh ketidakpastian, semakin kompleks, dan sangat dinamis menuntut para pengusaha untuk segera berubah dan adaptif melalui transformasi usaha. Proses transformasi usaha merupakan upaya strategis untuk meraih keunggulan bersaing sehingga dapat menghadapi kompetisi yang ada.

\section{Pengaruh Penerapan Total Quality Management terhadap terciptanya keunggulan bersaing}

Hasil hipotesa kelima membuktikan bahwa ada hubungan yang positif antara penerapan total quality management dengan terciptanya keunggulan bersaing dari perusahaan. Sejalan dengan teori Hunt, yang menyatakan "The drive for total quality management (TQM) has always been at the top of the agenda of many organizations in the private sector to improve quality, productivity, and competitive position”. TQM merupakan paradigma baru dalam menjalankan bisnis yang berupaya memaksimumkan daya saing organisasi melalui fokus pada kepuasan konsumen, keterlibatan seluruh karyawan, dan perbaikan secara berkesinambungan atas kualitas produk, jasa, manusia, proses dan lingkungan organisasi. 
Jurnal Riset Manajemen Sains Indonesia (JRMSI) | Vol 7, No. 1, 2016

Total Quality Management merupakan pendekatan untuk mendapatkan dan mempertahankan output yang berkualitas tinggi, fokus terhadap pemeliharaan, perbaikan yang berkelanjutan dan pencegahan kegagalan di semua level dan fungsi perusahaan, dalam rangka memenuhi atau melampaui harapan konsumen. Keunggulan bersaing merupakan kemampuan perusahaan untuk menciptakan nilai yang tidak dimiliki dan tidak dapat ditiru oleh pesaing

\section{KESIMPULAN DAN SARAN}

\section{Kesimpulan}

1. Terdapat pengaruh positif dan signifikan antara lingkungan eksternal dan penerapan Total Quality Management secara secara bersama-sama maupun secara langsung terhadap kinerja.

2. Terdapat pengaruh Positif dan signifikan antara lingkungan eksternal, penerapan Total Quality Management serta kinerja secara bersama - sama maupun secara langsung terhadap tercipatnya keunggulan bersaing.

\section{Saran}

Untuk pengembangan penelitian berikutnya, diharapkan ada penambahan variabel penelitian 


\section{DAFTAR PUSTAKA}

Aris Mardiyono, Pengaruh faktor lingkungan bisnis eksternal dan faktor manajerial terhadap perencanaan strategi untuk menngkatkan kinerja perusahaan, journal ilmiah, UNTAG semarang, 2010

Barney, Firm Resources and Sustained Competitive Advantage, Journal of Management, 17, 1991

Beal, R.M. “ Competing Effectively : Environment Scanning, Competitive Strategy \& Organization Performance in Small Manufacturing Firms". Journal of Small Business Management, 2000

David Hunger and Thomas Wheelen, Strategic Management and business Policy, 13th edition, Pearson Edition, Prentice Hall,2012

Dinda Mestika, Analisa pengaruh perencanaan strategi terhadap kinerja perusahaan dalam menciptakan keunggulan bersaing, UNDIP, 2006

Hansen and Mowen, Management Accounting 8th edition,Thomson - South Western,Oklahama University, 2007

Hunt, V. Daniel. Quality in America - How to Implement a Competitive Quality Program. Homewood, IL: Business One Irwin, 1992

Keats, B.W and Hitt A.K , 1998, a causal model of linkages among environment al dimensions, macro organizational characteristic and performance, academy of management journal, 1998 vol 31 No 3

Krajewski, J. Lee and P. R. Larry. Operations Management Strategy and Analysis, Fifth Edition, Addison-Wesley Publising Company Inc, 2003

Philip Kotler , Marketing Management ( 12 nd, ed, Prentice - Hall Inc. New Jersey,2002

Porter M.E, Competitive advantage : Creating and sustainin superior performance , NewYork, The free Press, 1998

Voss GB and Voss ZG, Strategic Orientation and firm performance in an artistic environment, journal of marketing ,2000 vol. 64

Walman, D.A , The Contribution of TQM to a theory of work performance , 1994 